\title{
Effects of Driving Torques on Direct Screw Withdrawal Resistance in OSB
}

\author{
*Onder TOR ${ }^{1}$, Samet DEMIREL ${ }^{2}$, Lingling HU $^{3}$, Jilei ZHANG ${ }^{4}$ \\ ${ }^{1}$ Kastamonu University, Faculty of Forestry, Forest Industrial Engineering, Kastamonu \\ ${ }^{2}$ Karadeniz Technical University, Faculty of Forestry, Forest Industrial Engineering, Trabzon \\ ${ }^{3}$ Zhejiang A\&F University, Department of Industrial Design, Hangzhou City, China \\ ${ }^{4}$ Mississippi State University, Department of Sustainable Bioproducts, Mississippi State, US \\ *Coressponding Author: ondertor@kastamonu.edu.tr
}

Geliş Tarihi: 13.10.2016

\begin{abstract}
This study was performed to evaluate effects of driving torques on direct screw withdrawal resistance (DSWR) in OSB. Pilot hole diameters (1.6, 2, $2.4 \mathrm{~mm}$ ), embedded screw orientations (edge-, end- and face-) and torque levels, that were obtained from the two main driving torques of seating and stripping, were selected to test on DSWR. The results of the study showed that the pilot hole diameters were needed to be chosen carefully related to the grain orientation and torque level. The DSWR in face orientation was higher than the ones in edge and end orientations. Based on the torque levels selected, the DSWR was lower at the torque level closer to the stripping torque levels in OSB.
\end{abstract}

Key Words:, Withdrawal resistance, Driving torque, Pilot hole diameter, Grain orientation, OSB

\section{Yönlendirilmiş Yonga Levhalarda Vidalama Torklarının Vida Çekme Direnci üzerine Etkisi}

\section{Özet}

$\mathrm{Bu}$ çalışmada vidalama torklarının vida çekme direnci üzerindeki etkileri araştırılmıştır. Bu amaçla, dikey yönde vida çekme direnci testinde kullanılacak test numuneleri kılavuz deliğinin çapına (1.6, 2, 2.4 $\mathrm{mm}$ ), vida çekme yönüne (kenar, son, ve yüzey) ve torklama seviyelerine göre hazırlanmıştır. Deney sonuçlarına göre, yüzey yönünde dikey çekme direnci diğer iki yöne göre daha yüksek dirence sahiptir. Vidalama tork seviyleri kıyaslandığında ise, vidanın boşta döndüğü torklama seviyelerinde, çekme direnci diğer seviyelere nazaran daha düşük seviyede olduğu bulunmuştur. Bu yüzden, vidalama yaparken özellikle kılavuz delik çalpları, vida çekme yönüne ve vidalama torkları seviyelerine göre dikkatli bir şekilde seçilmelidir.

Anahtar Kelimeler: Çekme direnci, Vidalama torkları, Kılavuz delik çapı, OSB

\section{Introduction}

The entirety of a structure is mostly dependent upon the connections amongst its component members. Each connection needs to be design based on the fastener type and strength properties of assembly components to meet maximum strength and stability. The recent study on driving torques in woodbased composites defined the driving torques which is the torque required to drive the screw into a pilot hole. In the study maximum drive torque (MDT) was defined as the torque at the first turning point on the torque curve where the clamping starts. The term of seating torque (SET) was the torque necessary to clamp parts. Stripping torque (STT) was the torque which is enough to cause the screw to fail in shear. Destruction torque is the torque that causes failure of the screw fastening system, and the term is more general than STT, covering other modes of failure, such as screw torsional failure and material splitting problem (Tor et al, 2015).

Torque requirements are affected by screw size, panel density, and depth of penetration. A strong relationship was found between SWR and torque strength in PB and reported that it is crucial to have significant difference between the amount of torque required to set the screw and the amount of torque required to strip the threads (Eckelman, 1990). In another study, overdriving screws substantially reduces DSWR and suggests that this important reduction in DSWR as a result of overdriving may contribute to particleboard's poor reputation for fastening with screws (Carroll, 1970). NPA (1968) indicated that there was a relationship between maximum drive torque and screw withdrawal strength on low 
density PB (480 to $640 \mathrm{~kg} / \mathrm{m} 3)$. However, Fujimoto and Mori (1983) disclosed no clear relationship between screw withdrawal resistance and torque resistance for commercial particleboard observing that torque resistance increases with increasing screw diameter whereas screw withdrawal resistance decreases. This suggests that torque resistance may not correlate well with screw withdrawal resistance over a wide range of particleboard types, and it may be preferable to use a hand-held screw extraction force tool that reads tensile load resistance directly.

The screw torque range and screw penetration depth had the highest effect on the maximum load $(\mathrm{N})$. By over-torqueing the screw, there was an average decrease of $728 \mathrm{~N}$ (77\%), and by under-torqueing the screw, there was an average decrease of 152 $\mathrm{N}(16 \%)$. This signifies the relevance of how the screw is driven. Over-torqueing the screw creates a higher risk of failure (Douglas, 2009).

Rajak and Eckelman (1993) low-density core can be easily damaged by the insertion of screws into pilot holes of an inappropriate size, further contributing to low screw holding ability. Because conventional screws require higher strength embedment materials, a range of alternative 'non-screw' connectors such as joining plates, dowels, or plugs made from wood, plastic, or metal have evolved for assembling particleboard furniture components (Schmidt 1986). Eckelman (1973) also reported a lead hole diameter range between $50 \%$ and $90 \%$ of screw root diameter does not seem to have much effect on torque requirement or withdrawal resistance in particleboard. Carroll (1970) reported that pilot-hole diameters between $40 \%$ and $70 \%$ of root diameter did not affect face withdrawal resistance of Douglas-fir plywood. The face withdrawal resistance decreased when the lead holes were $100 \%$ of screw root diameter, but the edge withdrawal resistance increased. This reflects the tendency of panels to split when screws are inserted into the edge of a panel. Eckelman (1975) reported screws driven completely through the main member had about $16 \%$ greater withdrawal resistance than screws of the same size that were driven their full length into a deeper member.

Many studies have been done in different areas such as human bone study. Lawson et al. (2001) reported that tightening unicortical screw into human tibia cortical bone to a high torque $(0.34 \quad \mathrm{~N} \cdot \mathrm{m} / \mathrm{mm})$ reduced withdrawal strength by about $24 \%$ as compared to low torque $(0.05 \mathrm{~N} \cdot \mathrm{m} / \mathrm{mm})$. Carter et al. (1984) and Jacobs et al. (1981) reported that when inserting bone screws to use as lag screws or through a compression plate, orthopedic surgeons adapt to what they perceive as the "optimal" torque depending on the bone quality, manually tightening and stopping before stripping occurs.

Therefore, the specific objectives were to 1) determine critical torque levels on the recorded driving torques; 2) obtain averaged values of critical screw withdrawal values on different torque levels; 3) investigate the effects of torque levels on screw direct withdrawal; and 4) investigate the effects of pilot-hole diameter and embedded screw orientation on different torques levels. It is believed that the DSWR study related to driving torques will help furniture manufacturers to set proper torques to drive screws into the material securely and safely, i.e., without material splitting.

\section{Material and Method \\ Experimental design}

A complete four-factor factorial experiment with 15 replications per combination was conducted to evaluate DSWR factors. The three factors were screw driven-in orientation embedded screw orientation (edge, end, and face) with reference to the full-size panel $(1.22$ by $2.44 \mathrm{~m})$ 2.44-m direction (machine direction), pilot hole diameter $(1.6,2$, and $2.4 \mathrm{~mm}$ which were $47 \%, 58 \%$, and $70 \%$ of the root diameter of a screw, respectively), and torque levels (seating and two different stripping torque levels, and three middle torque levels. Table 1 shows the torque levels within each combination of pilot-hole diameters and grain orientation in each material. Zhang et. al. (2002) defined three screw withdrawal directions as screw withdrawal perpendicular to the wood material wide surface will be 
face withdrawal, screw withdrawal perpendicular to the thickness surface will be edge withdrawal, and screw withdrawal perpendicular to grain direction will be end withdrawal. Edge and end-grain withdrawals will be side withdrawals.

Each testing block had nominal dimensions of $152.4-\mathrm{mm}$ long by $76.2-\mathrm{mm}$ wide by $18.26-\mathrm{mm}$ thick. 10 -gage, $38.1-\mathrm{mm}$ long flathead low carbon steel wood screws were used for this study. A 19- mm thick metal plate (Fig. 1) was used to ensure consistent screw penetration depths in the testing materials. Therefore, a total of 810 DSWR tests were performed on OSB blocks.

General linear model procedure for a three-factor balanced ANOVA was performed to analyze main effects and their interactions on means of withdrawal load of screws driven into tested material. The factors were embedded screw side orientation (edge and end), pilot hole diameter (1.6, 2, $2.4 \mathrm{~mm})$, and torque levels. Embedded screw side and face orientation were analyzed separately since the torque levels in those orientations were not the same. Therefore, in the case of faceorientation, ANOVA procedure was performed with three pilot hole-diameters and six different torque levels.

\section{Specimen preparation and measurements}

Testing blocks were cut from full-size panels of $18.26-\mathrm{mm}$ thick southern yellow pine, and conditioned in an equilibrium moisture content chamber controlled at $20 \pm$ $3^{\circ} \mathrm{C}$ and $65 \pm 2 \%$ relative humidity for two weeks. $19 \mathrm{~mm}$-deep pilot hole was drilled at the center of each edge and end testing block, whereas $12.7 \mathrm{~mm}$-deep pilot hole was drilled through its mid-surface of the face testing block (ASTM 2010a).

All torque measurements were performed immediately after the pilot holes were drilled into the testing blocks, followingly DSWR test was performed. Two different test setups were prepared to obtain driving torque and DSWR values, respectively. In the first test setup, the aim was to obtain the driving torque values, and then decide on the torque levels. Secondly, the DSWR test was performed to each specimen torqued at certain levels.

\section{Setting the torque levels}

Figure 1 shows the first setup for process of driving the screws into testing blocks by adjustable micrometer hand torque wrench at specified torque levels. This pro-grade wrench is preset to the correct torque and click tactilely and audibly when it reaches the correct torque being set. The wrench operating torque range was from 0 to 16.9 $\mathrm{N} \cdot \mathrm{m}$. The torque wrench was not returned to zero after every use not to damage its repeatability and accuracy. In the first step to set the torque levels, the screws were driven into the testing blocks at the seating torque level, than the stripping torque level to determine a range between these two tworque levels and following, determine three middle torque levels accurately in all orientations. Once clearifing these five torque levels, one more torque level was determined after the stripping torque level. The aim of setting the torque levels was to evaluate the effects of these six torque levels on the performance of DSWR later on. In second, the screws were driven into testing blocks by a screw driver until it reaches close enough to sit about $2 \mathrm{~mm}$ from the edge, end and surface of the block, and then the torque applied at certain levels by a torque wrench. The application of the torque by the wrench increased $0.1 \mathrm{~N} \cdot \mathrm{m}$ by $0.1 \mathrm{~N} \cdot \mathrm{m}$ in order to reach the torque level specified.

A single test group consisted of 15 testing blocks allowing a total of 80 testing blocks was constituted for each combination of pilot-hole diameter and grain-orientation. The five testing blocks in a group driven screws in were determined at first and prepared for the DSWR test immediately. 


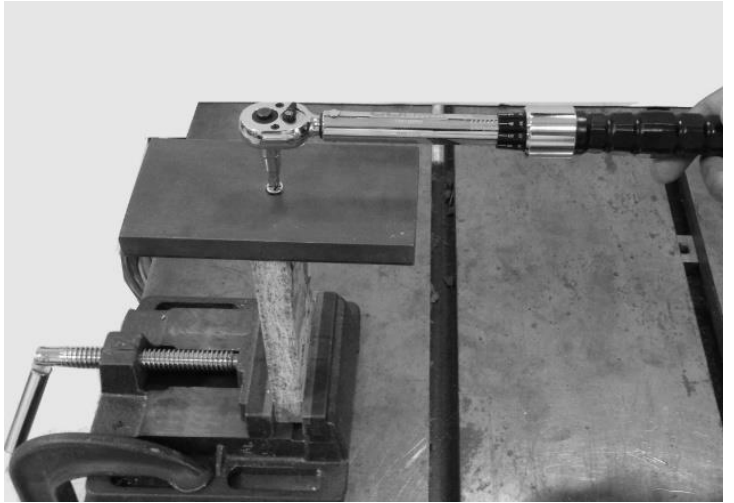

(a)

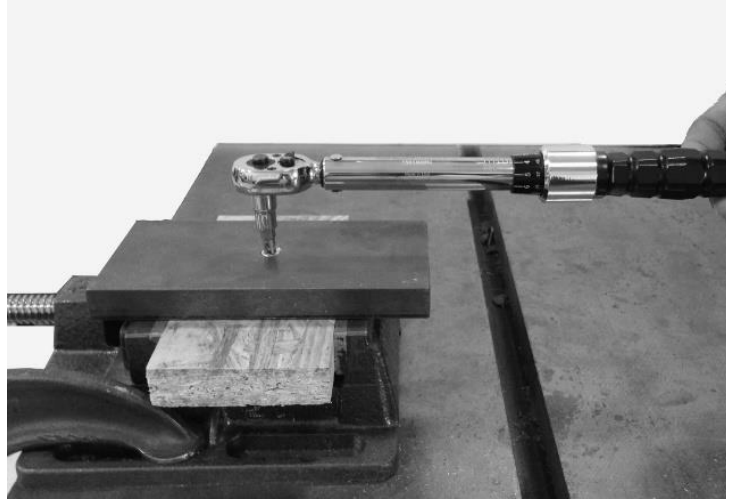

(b)

Figure 1. Test setup for setting the torque values in side-grain (a) and face-grain (b).

\section{DSWR test}

The second test setup was for the DSWR test with two different setups one of which was used for side-grain, and other one was for face-grain withdrawals, shown in Figure $2 \mathrm{a}$ and $2 \mathrm{~b}$, respectively. All of the DSWR tests were carried out on a Instron 8880 Servo-Hydraulic Universal Testing Machine operated at a constant head speed of $1.5 \mathrm{~mm}$ per minute in accordance with ASTM standards D1037-72 (2003a) and D1761 (ASTM 2003b).

The ultimate withdrawal load was recorded and ended in about 25 seconds in side-withdrawal, and 40 seconds in facewithdrawal. The displacement of the crosshead was also measured and was assumed to represent the withdrawal displacement of wood screw.

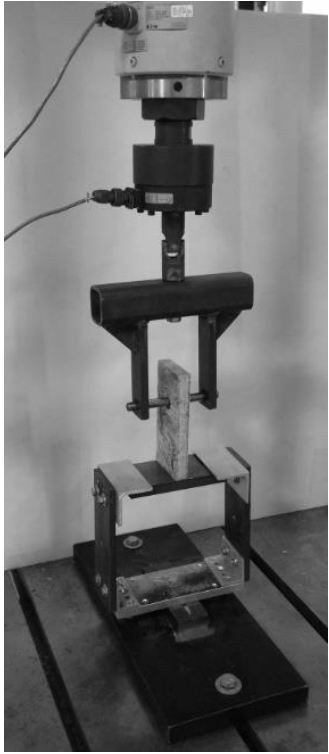

(a)

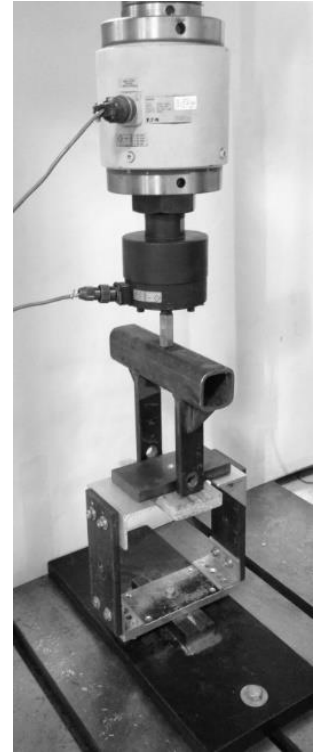

(b)
Figure 2. Test setup for DSWR in side-grain (a) and face-grain (b).

\section{Results and Discussion}

Table 1 summarizes the mean values of measured density, including overall, core, and surface density, the percentage of moisture content (MC), and internal bond value of OSB material evaluated in this study. The typical density profiles of OSB material was illustrated in Figure 3. 
Figure 3. Typical density profiles of OSB material evaluated in this study.

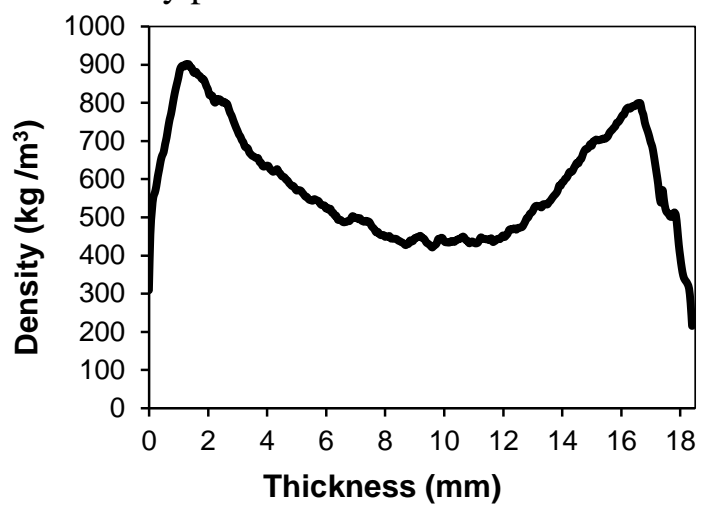

Table 1. Physical and mechanical properties of OSB.

\begin{tabular}{ccccc}
\hline \multicolumn{3}{c}{ Density $\left(\mathrm{kg} / \mathrm{m}^{3}\right)$} & & \\
\cline { 1 - 3 } Overall & Core & Surface & MC $(\%)$ & Internal bond (MPa) \\
\hline $570(24)^{\mathrm{a}}$ & $450(7)$ & $880(6)$ & $6.8(6)$ & $0.69(24)$
\end{tabular}

${ }^{a}$ Values in parentheses are coefficient of variation (\%).

\section{Torque Levels}

Table 2 shows the torque levels specified. The torque levels were ranged between 1.4 as seating torque level and $4.2 \mathrm{~N} \cdot \mathrm{m}$ as stripping torque level in edge and end withdrawal directions and between 1.9 as seating torque level and $6.2 \mathrm{~N} \cdot \mathrm{m}$ as stripping torque level in face-grain in OSB.

\section{DSWR Curves}

Figure 5 shows two typical load-extension curves recorded during DSWR test for endand face-orientation. The extension for sideorientation reached maximum at $2 \mathrm{~mm}$ where there was a sudden decrease in withdrawal load. In the case of the face-orientation, the withdrawal load started decreasing gradually after the extension had reached at $1.5 \mathrm{~mm}$.

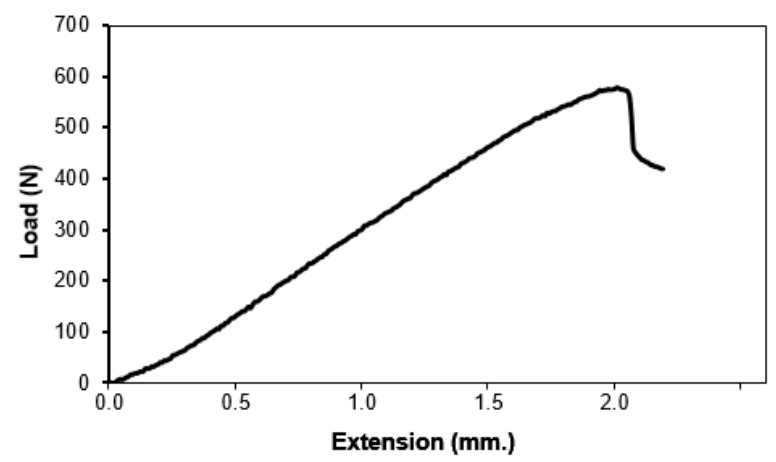

(a)

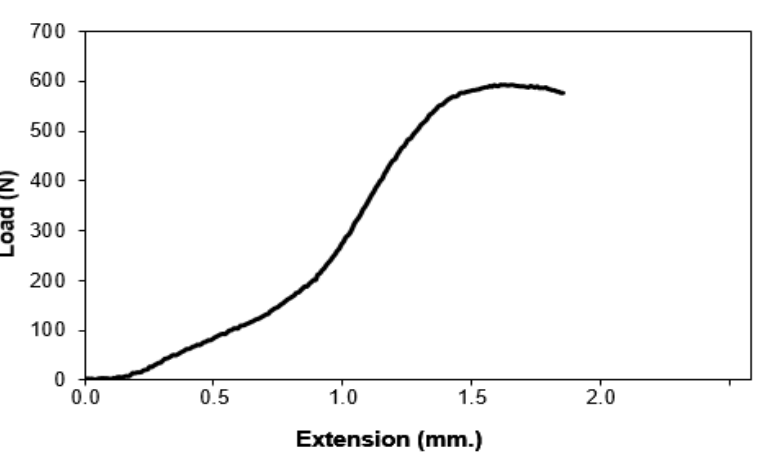

(b)

Figure 5. Load-extension curve of screw withdrawal test into end (a) and face (b) of tested wood-based composites in this study.

\section{Mean DSWR}

Table 2 summarizes the results of mean ultimate withdrawal load values and their coefficients of variation for the screw direct pull study by grain orientation, pilot-hole diameter, and torque levels in OSB. The mean screw withdrawal load value of each combination represents the mean withdrawal load of one direct screw pull from one specimen.

Mean ultimate withdrawal load ranged from a low value of $716 \mathrm{~N}$ for sidewithdrawal with a 2-mm diameter to a high value of $2949 \mathrm{~N}$ for face withdrawal with a 2.4-mm diameter. Coefficients variations of withdrawal load values ranged from $5 \%$ to $30 \%$. 
Table 2. Mean withdrawal load and their coefficient of variance (COV) at torque levels in each withdrawal direction in OSB.

\begin{tabular}{|c|c|c|c|}
\hline $\begin{array}{l}\text { Withdrawal } \\
\text { direction }\end{array}$ & $\begin{array}{l}\text { Pilot-hole } \\
\text { diameter }\end{array}$ & Torque level & Load \\
\hline \multirow{19}{*}{ Edge } & $(\mathrm{mm})$ & $(\mathrm{N} \cdot \mathrm{m})$ & $(\mathrm{N})$ \\
\hline & 1.6 & 1.5 & $2095(27)$ \\
\hline & & 1.7 & $1979(28)$ \\
\hline & & 2.3 & $1997(18)$ \\
\hline & & 2.8 & $1655(22)$ \\
\hline & & 4.2 & $1103(17)$ \\
\hline & & After splitting & $716(10)$ \\
\hline & 2 & 1.4 & $1606(22)$ \\
\hline & & 1.7 & 2304 (12) \\
\hline & & 2.3 & $2433(17)$ \\
\hline & & 2.8 & $1552(30)$ \\
\hline & & 4.0 & $1134(10)$ \\
\hline & & After splitting & $676(9)$ \\
\hline & 2.4 & 1.6 & $1859(24)$ \\
\hline & & 1.7 & $2589(15)$ \\
\hline & & 2.3 & $1584(26)$ \\
\hline & & 2.8 & $1406(12)$ \\
\hline & & 4.5 & $1121(15)$ \\
\hline & & After splitting & $827(12)$ \\
\hline \multirow[t]{18}{*}{ End } & 1.6 & 1.5 & $1557(22)$ \\
\hline & & 1.7 & $2211(20)$ \\
\hline & & 2.3 & $1721(24)$ \\
\hline & & 2.8 & $2082(19)$ \\
\hline & & 4.0 & 1379 (18) \\
\hline & & After splitting & $712(19)$ \\
\hline & 2 & 1.6 & $2011(13)$ \\
\hline & & 1.7 & $1948(20)$ \\
\hline & & 2.3 & $1931(15)$ \\
\hline & & 2.8 & $1988(21)$ \\
\hline & & 4.4 & 1214 (11) \\
\hline & & After splitting & $810(12)$ \\
\hline & 2.4 & 1.4 & $1477(23)$ \\
\hline & & 1.7 & 2509 (17) \\
\hline & & 2.3 & $2086(18)$ \\
\hline & & 2.8 & $2220(17)$ \\
\hline & & 4.3 & 1059 (11) \\
\hline & & After splitting & 814 (14) \\
\hline \multirow[t]{18}{*}{ Face } & 1.6 & 1.9 & $2086(17)$ \\
\hline & & 2.5 & $2820(7)$ \\
\hline & & 3.7 & $1939(5)$ \\
\hline & & 5.0 & 2527 (11) \\
\hline & & 6.2 & $1054(20)$ \\
\hline & & After splitting & $707(16)$ \\
\hline & 2 & 1.9 & $2598(15)$ \\
\hline & & 2.5 & $2656(14)$ \\
\hline & & 3.7 & 2664 (19) \\
\hline & & 5.0 & $2642(14)$ \\
\hline & & 6.2 & 1028 (13) \\
\hline & & After splitting & $818(11)$ \\
\hline & 2.4 & 2.0 & $2469(14)$ \\
\hline & & 2.5 & $2442(12)$ \\
\hline & & 3.7 & 2949 (19) \\
\hline & & 5.0 & $2656(11)$ \\
\hline & & 6.2 & $1010(20)$ \\
\hline & & After splitting & 734 (19) \\
\hline
\end{tabular}

ANOVA results of screw withdrawal loads indicated that there three-factor interaction was significant $(p$-value $=<0.001)$ at the 5 percent significance. Therefore, a one-way classification of 36 treatment combinations amongst pilot hole diameter, embedded screw side orientation, and torque level was created for screw withdrawal load, to evaluate mean differences among different combinations (Tables 3, 5, and 6) using the protested least significant difference (LSD) multiple comparison procedure. The LSD value for withdrawal load was $367 \mathrm{~N}$.

In the case of face-orientation in OSB, ANOVA results showed that the two-way interaction between pilot hole diameter and torque level was significant ( $p$ value $=<0.001)$ at the 5 percent significance. Therefore, a one-way classification of 18 treatment combinations amongst pilot hole diameter and torque level was created for screw withdrawal load, to evaluate mean differences among different combinations (Tables 4 and 7) using the protested least significant difference (LSD) multiple comparison procedure. The LSD value for withdrawal load was $339 \mathrm{~N}$.

\section{Torque level effects}

In general, table 3 and 4 show the mean comparisons of screw withdrawal load values of torque levels within each combination of pilot-hole diameter edge \& end and face withdrawal directions in OSB, respectively. The results indicated that the ultimate withdrawal load at the stripping torque levels was lower than the other torque levels in all

pilot-hole diameters in edge- and end- grain in OSB. In most of the combinations, the torque levels closer to the seating torque had the highest ultimate withdrawal, except two cases. The ultimate withdrawal load was highest in the seating torque levels in the pilot-hole diameter of $1.6 \mathrm{~mm}$ in edgewithdrawal and $2 \mathrm{~mm}$ in end-withdrawal.

In the case of face-grain orientation, table 4 show the mean comparison of torque levels in all diameters in OSB, respectively. In general, the stripping torque levels had lower ultimate withdrawal load than the other levels, having the second stripping level lowest. There was no significant difference among the first torque levels with a 2-mm diameter in OSB. 
Table 3. Mean comparisons of screw withdrawal load values of torque levels within each combination of pilot-hole diameter and withdrawal direction in OSB.

\begin{tabular}{|c|c|c|c|c|c|c|c|}
\hline \multirow{2}{*}{$\begin{array}{c}\text { Withdrawal } \\
\text { direction }\end{array}$} & \multirow{2}{*}{$\begin{array}{c}\text { Pilot-hole } \\
\text { diameter }\end{array}$} & \multicolumn{6}{|c|}{ Torque Level $(\mathrm{N} \cdot \mathrm{m})$} \\
\hline & & 1.5 & 1.7 & 2.3 & 2.8 & 4.2 & After splitting \\
\hline \multirow{4}{*}{ Edge-grain } & $(\mathrm{mm})$ & & & & $(\mathrm{N})-------$ & & ------------- \\
\hline & 1.6 & $2095 \mathrm{~A}^{\mathrm{a}}$ & $1979 \mathrm{AB}$ & $1997 \mathrm{AB}$ & $1655 \mathrm{~B}$ & $1103 \mathrm{C}$ & $716 \mathrm{D}$ \\
\hline & 2 & $1606 \mathrm{~B}$ & $2304 \mathrm{~A}$ & 2433 A & $1552 \mathrm{~B}$ & $1134 \mathrm{C}$ & $676 \mathrm{D}$ \\
\hline & 2.4 & $1859 \mathrm{~B}$ & $2589 \mathrm{~A}$ & $1584 \mathrm{BC}$ & $1406 \mathrm{C}$ & $1121 \mathrm{C}$ & $827 \mathrm{C}$ \\
\hline \multirow[t]{3}{*}{ End-grain } & 1.6 & $1557 \mathrm{~B}$ & $2211 \mathrm{~A}$ & $1721 \mathrm{AB}$ & $2082 \mathrm{~A}$ & $1379 \mathrm{C}$ & $712 \mathrm{D}$ \\
\hline & 2 & $2011 \mathrm{~A}$ & 1948 A & $1931 \mathrm{~A}$ & $1988 \mathrm{~A}$ & $1214 \mathrm{~B}$ & $810 \mathrm{C}$ \\
\hline & 2.4 & $1477 \mathrm{C}$ & $2509 \mathrm{~A}$ & $2086 \mathrm{~B}$ & $2220 \mathrm{AB}$ & $1059 \mathrm{D}$ & $814 \mathrm{D}$ \\
\hline
\end{tabular}

${ }^{a}$ Means not followed by a common letter are significantly different one from another at the $5 \%$ significance level.

Table 4. Mean comparisons of screw withdrawal load values of torque level within each pilothole diameter in face-withdrawal in OSB.

\begin{tabular}{cccccccc}
\hline \multirow{2}{*}{$\begin{array}{c}\text { Withdrawal } \\
\text { direction }\end{array}$} & $\begin{array}{c}\text { Pilot-hole } \\
\text { diameter }\end{array}$ & \multicolumn{7}{c}{ Torque Level (N·m) } \\
\cline { 3 - 7 } Face-grain & $(\mathrm{mm})$ & --9.9 & 2.5 & 3.7 & 5.0 & 6.2 & After splitting \\
& 1.6 & $2086 \mathrm{~B}^{\mathrm{a}}$ & $2820 \mathrm{~A}$ & $1939 \mathrm{~B}$ & $2527 \mathrm{~A}$ & $1054 \mathrm{C}$ & $707 \mathrm{D}$ \\
& 2 & $2598 \mathrm{~A}$ & $2656 \mathrm{~A}$ & $2664 \mathrm{~A}$ & $2642 \mathrm{~A}$ & $1028 \mathrm{~B}$ & $818 \mathrm{~B}$ \\
& 2.4 & $2469 \mathrm{~B}$ & $2442 \mathrm{~B}$ & $2949 \mathrm{~A}$ & $2656 \mathrm{AB}$ & $1010 \mathrm{C}$ & $734 \mathrm{D}$ \\
\hline
\end{tabular}

${ }^{a}$ Means not followed by a common letter are significantly different one from another at the $5 \%$ significance level.

\section{Embedded screw orientation effect}

In general, table 5 shows the mean withdrawal comparison of the side-embedded screw orientations in the combination of torque level and pilot-hole diameter. The results showed that at the stripping torque level and the level after stripping, there was no significant influence on the ultimate withdrawal load in all combinations, except one case. The end-screw embedded orientation had higher ultimate withdrawal load than the edge-one in the torque level of $4 \mathrm{~N} \cdot \mathrm{m}$. The same trend occurred at the torque level of $2.8 \mathrm{~N} \cdot \mathrm{m}$ in all pilot-hole diameters.

Table 5. Mean comparisons of screw withdrawal load values of screw withdrawal direction within each combination of torque level and screw withdrawal direction in OSB.

\begin{tabular}{cccc}
\hline \multirow{2}{*}{ Pilot-hole diameter } & \multirow{2}{*}{ Torque level } & \multicolumn{2}{c}{ Withdrawal direction } \\
\cline { 3 - 4 } & & Edge-grain & End-grain \\
\hline$(\mathrm{mm})$ & $(\mathrm{N} \cdot \mathrm{m})$ & $-----------(\mathrm{N})----------$ \\
1.6 & 1.5 & $2095 \mathrm{~A}^{\mathrm{a}}$ & $1557 \mathrm{~B}$ \\
& 1.7 & $1979 \mathrm{~A}$ & $2211 \mathrm{~A}$ \\
& 2.3 & $1997 \mathrm{~A}$ & $1721 \mathrm{~A}$ \\
& 2.8 & $1655 \mathrm{~B}$ & $2082 \mathrm{~A}$ \\
& 4.2 & $1103 \mathrm{~B}$ & $1379 \mathrm{~A}$ \\
& After splitting & $716 \mathrm{~A}$ & $712 \mathrm{~A}$ \\
\hline \multirow{2}{*}{2} & 1.5 & $1606 \mathrm{~B}$ & $2011 \mathrm{~A}$ \\
& 1.7 & $2304 \mathrm{~A}$ & $1948 \mathrm{~B}$ \\
& 2.3 & $2433 \mathrm{~A}$ & $1931 \mathrm{~B}$ \\
& 2.8 & $1552 \mathrm{~B}$ & $1988 \mathrm{~A}$ \\
& 4.2 & $1134 \mathrm{~A}$ & $1214 \mathrm{~A}$ \\
& After splitting & $676 \mathrm{~A}$ & $810 \mathrm{~A}$ \\
\hline \multirow{2}{*}{2.4} & 1.5 & $1859 \mathrm{~A}$ & $1477 \mathrm{~B}$ \\
& 1.7 & $2589 \mathrm{~A}$ & $2509 \mathrm{~A}$ \\
& 2.3 & $1584 \mathrm{~B}$ & $2086 \mathrm{~A}$ \\
\hline & 2.8 & $1406 \mathrm{~B}$ & $2220 \mathrm{~A}$ \\
& 4.2 & $1121 \mathrm{~A}$ & $1059 \mathrm{~A}$ \\
& After splitting & $827 \mathrm{~A}$ & $814 \mathrm{~A}$ \\
\hline
\end{tabular}

${ }^{a}$ Means not followed by a common letter are significantly different one from another at the 5\% significance level. 
In general, table 6 shows the mean comparison of the pilot-hole diameters in the combination of torque level and sideembedded screw orientation. The results demonstrated that there was no significant difference among the pilot-hole diameters in higher torque levels of 2.8, 3.4 and the level after splitting in both side-withdrawal loads. For the other torque levels, there was no clear trend on ultimate withdrawal load. The pilot-hole diameters differed at the torque level of $2.3 \mathrm{~N} \cdot \mathrm{m}$ in edge-withdrawal. The pilot-hole diameter of 2-mm had the highest ultimate withdrawal load whereas the 2.4$\mathrm{mm}$ diameter had the lowest.

In the case of face-grain orientation, table 7 shows the mean comparison of pilot-hole diameter in all torque levels in OSB. In general, there was no statistically significant difference in the withdrawal loads of OSB specimens at three highest torque levels. As occurred in side-withdrawal, two stripping torque levels had significantly lower withdrawal load than the other levels, having the first stripping torque level higher than the second. The face-withdrawal with a $2-\mathrm{mm}$ and 2.4-mm diameter did not differ from each other where they were significantly higher than the one with a $1.6-\mathrm{mm}$ diameter at the seating torque level of $1.9 \mathrm{~N} \cdot \mathrm{m}$.. The same trend occurred in the torque level of 3.7 $\mathrm{N} \cdot \mathrm{m}$.

Table 6. Mean comparisons of screw withdrawal load values of pilot-hole diameter within each combination of torque level and screw withdrawal direction in OSB.

\begin{tabular}{ccccc}
\hline \multirow{2}{*}{ Withdrawal direction } & \multirow{2}{*}{ Torque level } & \multicolumn{3}{c}{ Pilot hole diameter $(\mathrm{mm})$} \\
\cline { 3 - 5 } & & 1.6 & 2 & 2.4 \\
\hline \multirow{3}{*}{ Edge-grain } & $(\mathrm{N} \cdot \mathrm{m})$ & $-----------------(\mathrm{N})----------------$ \\
& 1.5 & $2095 \mathrm{~A}^{\mathrm{a}}$ & $1606 \mathrm{~B}$ & $1859 \mathrm{AB}$ \\
& 1.7 & $1979 \mathrm{~B}$ & $2304 \mathrm{AB}$ & $2589 \mathrm{~A}$ \\
& 2.3 & $1997 \mathrm{~B}$ & $2433 \mathrm{~A}$ & $1584 \mathrm{C}$ \\
& 2.8 & $1655 \mathrm{~A}$ & $1552 \mathrm{~A}$ & $1406 \mathrm{~A}$ \\
& 4.2 & $1103 \mathrm{~A}$ & $1134 \mathrm{~A}$ & $1121 \mathrm{~A}$ \\
& After splitting & $716 \mathrm{~A}$ & $676 \mathrm{~A}$ & $827 \mathrm{~A}$ \\
\hline
\end{tabular}

Table 6. (continued)

\begin{tabular}{ccccc} 
End-grain & 1.5 & $1557 \mathrm{~B}$ & $2011 \mathrm{~A}$ & $1477 \mathrm{~B}$ \\
& 1.7 & $2211 \mathrm{AB}$ & $1948 \mathrm{~B}$ & $2509 \mathrm{~A}$ \\
& 2.3 & $1721 \mathrm{~B}$ & $1931 \mathrm{AB}$ & $2086 \mathrm{~A}$ \\
& 2.8 & $2082 \mathrm{~A}$ & $1988 \mathrm{~A}$ & $2220 \mathrm{~A}$ \\
& 4.2 & $1379 \mathrm{~A}$ & $1214 \mathrm{~A}$ & $1059 \mathrm{~A}$ \\
& After splitting & $712 \mathrm{~A}$ & $810 \mathrm{~A}$ & $814 \mathrm{~A}$ \\
\hline
\end{tabular}

${ }^{a}$ Means not followed by a common letter are significantly different one from another at the $5 \%$ significance level.

Table 7. Mean comparisons of screw withdrawal load values of pilot-hole diameter within each of torque level in face-withdrawal in OSB.

\begin{tabular}{|c|c|c|c|c|}
\hline \multirow{2}{*}{ Withdrawal direction } & \multirow{2}{*}{ Torque level } & \multicolumn{3}{|c|}{ Pilot hole diameter (mm) } \\
\hline & & 1.6 & 2 & 2.4 \\
\hline \multirow{7}{*}{ Face-grain } & $(\mathrm{N} \cdot \mathrm{m})$ & ------ & ---(N)----- & ---- \\
\hline & 1.9 & $2086 \mathrm{~B}^{\mathrm{a}}$ & $2598 \mathrm{~A}$ & $2469 \mathrm{~A}$ \\
\hline & 2.5 & $2820 \mathrm{~A}$ & $2656 \mathrm{AB}$ & 2442 B \\
\hline & 3.7 & $1939 \mathrm{~B}$ & $2664 \mathrm{~A}$ & 2949 A \\
\hline & 5.0 & $2527 \mathrm{~A}$ & $2642 \mathrm{~A}$ & $2656 \mathrm{~A}$ \\
\hline & 6.2 & $1054 \mathrm{~A}$ & $1028 \mathrm{~A}$ & $1010 \mathrm{~A}$ \\
\hline & After splitting & $707 \mathrm{~A}$ & $818 \mathrm{~A}$ & $734 \mathrm{~A}$ \\
\hline
\end{tabular}

${ }^{a}$ Means not followed by a common letter are significantly different one from another at the 5\% significance level.

\section{Conclusion}

Effects of embedded screw orientation, pilot-hole diameter, and torque levels on the resistance of OSB was investigated on the direct withdrawal of screws. In general, the torque levels affected the direct screw withdrawal resistance. The lowest withdrawal load occurred at the second 
stripping torque levels within all diameters for all screw embedded orientation. The results of embedded screw orientation analysis indicated that there was no significant difference in the side-withdrawal loads in two stripping torque levels, except one case. The ultimate withdrawal load in end-embedded screw orientation was higher than the edge in the torque level of $4 \mathrm{~N} \cdot \mathrm{m}$. The same trend occurred at the torque level of $2.8 \mathrm{~N} \cdot \mathrm{m}$ in all pilot-hole diameters. There was significant difference among the screw embedded orientations at the seating torque level of $1.6 \mathrm{~N} \cdot \mathrm{m}$ in OSB.

\section{Acknowledgements}

Special thanks to the Department of Sustainable Bioproducts and Forest and Wildlife Research Center, Mississippi State University, MS State, USA.

\section{References}

ASTM 2010a D-1761-06. Standard test method for mechanical fasteners in wood, American Society for Testing and Materials, West Conshohocken, PA.

ASTM 2010b D 1037-06. Standard test methods for evaluating properties of wood-base fiber and particle panel materials, American Society for Testing and materials, West Conshohocken, PA.

ASTM 2010c D 4442-92. Standard test methods for direct moisture content measurement of wood and wood-base materials. American Society for Testing and materials, West Conshohocken, PA.

Carroll, M.N., 1970. Relationship between driving torque and screw-holding strength in particleboard and plywood. Forest Prod J 20(3): 24-29.

Carter, D.R., Shimaoka, E.E., Harris, W.H., et al., 1984. Changes in long-bone structural properties during the first 8 weeks of plate implantation. Journal of Orthopaedic Research 2 (1), 80-89.

Didriksson, E.I.E., Nyren, J.O., Back, E.L., 1974. The splitting of wood-base building boards due to edge screwing. Forest Prod J 24(7):35-39.

Eckelman, C.A, 1990. Fasteners and their use in particleboard and medium density fiberboard. National Particleboard Association. Purdue University.

Eckelman, C.A., 1973. Holding strength of screws in wood and wood-base materials. Res.
Rept. No. 895. Agric. Expt. Sta. Purdue University, West Lafayette, Ind. pp:15.

Eckelman, C.A., 1975. Screw-holding performance in hardwoods and particleboard. Forest Products Jornal 25(6):30-35.

Eckelman, C.A., 1990. Fasteners and their use in particleboard and medium density fiberboard. National Particleboard Association. Purdue University.

Fujimoto, Y. and Mori, M., 1983. Performance of Wood Screw Joints for Particleboard. Science Bulletin of the Faculty of Agriculture, Kyushu

University, Japan 30(1): 45-47.

Jacobs, R., Rahn, B., Perren, S., 1981. Effect of plates on cortical bone perfusion. The Journal of Trauma 21 (2), 91-95.

Lawson, K.J., Brems, J., 2001. Effect of insertion torque on bone screw pullout strength. Orthopedics 24(5):451-454.

National Particleboard Association, 1968. Screw holding of particleboard. Tech. Bull. No. 3, Washington, D.C.

Rajak. Z., Eckelman, C.A., 1993. Edge and face withdrawal strength of large screws in particleboard and medium density fiberboard. Forest Prod J 43(4):25-30.

Schmidt, H. 1986. Industrial particleboard: Application requirements and special manufacturing features. In: Proc. of the 20th WSU International Particleboard/Composite Materials Symp. T.M. Maloney, Ed. Washing State Univ., Pullman, WA, pp. 343-354.

Tor, O., Yu, X., Zhang, J., 2015. Characteristics of torques for driving screws into wood-based composites. Wood Fiber Sci 47(1).

Yu, X., Tor, O., Quin, F., Seale, D., Zhang, J., 2015. Screwdriving torques in particleboards. Wood Fiber Sci 47(2).

Zhang, J. and Eckelman, C. 2002. Holding strength of screws in plywood and oriented strandboard. Forest Prod J 52(6):55-62. 